\title{
Happy Free Willies? Investigating the relationship between freelancing and subjective well-being
}

\author{
Peter van der Zwan • Jolanda Hessels • \\ Martijn Burger
}

Accepted: 1 March 2019/Published online: 22 August 2019

(C) The Author(s) 2019

\begin{abstract}
In recent years, there has been a steady increase in the number of own-account workers (the selfemployed without employees), including freelancers, in many developed economies. Despite the importance of the group of freelancers for modern economies, little is known about the perceived benefits of freelancing. We use six waves of the United Kingdom Household Longitudinal Study (“Understanding Society”, 2009-2015) to investigate subjective well-being levels of freelancers in terms of satisfaction with life, work, leisure time, income and health. Although freelancing jobs are uncertain and temporary, our cross-sectional (pooled ordinary least squares (OLS)) and longitudinal (fixed-
\end{abstract}

P. van der Zwan $(\bowtie)$

Department of Business Studies, Institute of Tax Law and Economics, Leiden Law School, Leiden University, Leiden, the Netherlands

e-mail: p.w.van.der.zwan@law.leidenuniv.nl

J. Hessels · M. Burger

Department of Applied Economics, Erasmus School of

Economics, Erasmus University Rotterdam, Rotterdam, the

Netherlands

\section{J. Hessels · M. Burger}

Erasmus Happiness Economics Research Organisation (EHERO), Erasmus School of Economics, Erasmus University Rotterdam, Rotterdam, the Netherlands

J. Hessels

Erasmus Research Institute of Management, Rotterdam, the

Netherlands

J. Hessels · M. Burger

Tinbergen Institute, Rotterdam, the Netherlands effects) analyses reveal that freelancers are on par regarding life satisfaction with other own-account workers, employers (self-employed workers with employees) and wage workers. The most striking result is that freelancers are significantly more satisfied with their leisure time than other own-account workers, employers and wage workers. Also, freelancers score significantly higher in terms of work satisfaction than wage workers, but do not exceed other own-account workers and employers in terms of work satisfaction. Freelancers are equally satisfied with their health as other ownaccount workers and employers. In sum, the analysis of several subdomains of life reveals much how different groups of self-employed workers score regarding their overall subjective well-being.

Keywords Freelancers · Independent professionals . Own-account workers · Solo self-employment .

Subjective well-being $\cdot$ Satisfaction

JEL classification I31 $\cdot$ J28 $\cdot$ L24 $\cdot$ L26

\section{Introduction}

Many European economies have experienced substantial increases in own-account workers (self-employed individuals without employees; also known as solo selfemployed workers) over the recent decades. Freelancers, or independent professionals, are an important subgroup among the heterogeneous group of own-account workers (Van den Born and Van Witteloostuijn 2013). The 
freelance workforce has expanded to about 2 million workers in 2015 in the UK and represents about $40 \%$ of the own-account workers and $30 \%$ of all self-employed workers (Kitching 2015). In some sectors, such as media, the majority of workers are freelancers (Storey et al. 2005). Freelancers work for their own risk while being hired by companies and selling their intangible knowledge. In other words, they are a hybrid between entrepreneurs and wage workers (Van den Born and Van Witteloostuijn 2013). Freelancers differentiate from other own-account workers by their (preference for) temporary work and the knowledge/skill-intensive services they provide (Kitching and Smallbone 2012).

Despite the widespread phenomenon of own-account workers and freelancers in modern economies, there is hardly any insight in the drivers of freelancers to engage in such behaviour. Although their jobs are characterised by uncertainty and their temporary character, there is not much known about whether there are any (perceived) gains of freelancing compared with other self-employed work. Unsurprisingly, researchers have started to inquire the quality of the jobs of own-account workers (Van Stel and Van der Zwan 2019) and freelancers (Meager 2015), for example in terms of work satisfaction (Meager 2015). In the present paper, we add to this research lacuna by analysing the subjective well-being levels of freelancers to retrieve more knowledge about their drivers to engage in freelancing activities, and the benefits they perceive of engaging in such activities. We compare their subjective well-being levels with other own-account workers, with employers (self-employed workers who have employees) and with wage workers.

Subjective well-being refers to how people think and feel about their lives (Dolan et al. 2008). An important component of subjective well-being is life satisfaction (Diener et al. 1999). Much research has analysed people's cognitive evaluations of their lives using largescale surveys and has associated these evaluations with various (individual-level) characteristics (for an overview, see Dolan et al. 2008). In the work domain, for example, there has been an increased interest in the topic of subjective well-being, not the least because of the positive link between satisfaction and productivity (Oswald et al. 2015). Subjective well-being within the domain of self-employment, and freelancing or ownaccount work more specifically, has been an underresearched theme until now.

The present paper has three contributions. The first contribution is that it is the first to empirically address the relationship between freelancing and subjective well-being. Given the widespread prevalence of freelancers and the continuing emergence of this group in modern economies such as the UK, it is relevant to know how the subjective well-being levels of this group compare with other own-account workers and employers. ${ }^{1}$

The second contribution of the present paper is that it unravels whether subjective well-being differences can be observed within the group of self-employed workers. We already know that the group of self-employed workers is heterogeneous, and earlier research reveals a life satisfaction premium for the self-employed who start a business because of opportunity rather than necessity reasons (Binder and Coad 2013; Larsson and Thulin 2018). In addition, Hessels et al. (2018) focus on collar type and skill level and find that white-collar and high-skilled self-employed workers are generally more satisfied with their lives than blue-collar and low-skilled self-employed workers. A comparison of subjective well-being differences by means of a range of "domain satisfactions" (Erdogan et al. 2012) within the group of self-employed workers-having employees or not-and the group of own-account workers-freelancers versus other own-account workers - has, however, not yet been provided. ${ }^{2}$

The third contribution is that we perform a joint analysis of satisfaction levels with several domains in life including work, leisure, income, and health (the domain satisfactions). In other words, we apply a "life domain view" (Binder and Coad 2016) in that we acknowledge that satisfaction with life is a function of satisfaction with a range of domains in life (Erdogan et al. 2012). Hence, disentangling these domains may provide useful information on well-being outcomes across (self-employed) workers. We do so in a longitudinal context by using panel data covering six waves from the UK Household Longitudinal Study ("Understanding Society"; 2009-2015), allowing exploiting variation over time within individuals.

The set-up of the paper is as follows. In the subsequent section, we provide an overview of the existing literature, followed by the data and methodology

\footnotetext{
${ }^{1}$ See Binder (2018) for a univariate comparison of several groups within self-employment including freelancers.

${ }^{2}$ A small set of studies focus on one or two subjective well-being measures and compare the own-account workers with the employer entrepreneurs (Prottas and Thompson 2006; Kara and Petrescu 2018).
} 
(Section 3), the results (Section 4) and a discussion and conclusion (Section 5).

\section{Literature overview}

Self-employment has traditionally been linked with higher levels of satisfaction with one's work compared with wage employment. Higher levels of work satisfaction among the self-employed compared with wage workers have been explained by the non-monetary rewards that self-employment offers (Benz and Frey 2008). Indeed, the self-employed derive "procedural utility" from being their own boss which enhances work satisfaction (Benz and Frey 2008).

Few studies have been conducted on the relationship between self-employment (versus wage employment) and life satisfaction. There is some evidence of a life satisfaction premium for the self-employed (Andersson 2008; Binder and Coad 2013; Blanchflower and Oswald 1998; Hessels et al. 2018; Stephan and Roesler 2010), but the evidence is not as conclusive as for work satisfaction. That is, there are also studies that do not find a significant relationship at all (Di Tella et al. 2003), at least in some countries, or some studies even find a negative relationship (Salinas-Jiménez et al. 2013).

In the present paper, we do not focus on the difference between self-employed workers and wage workers, but are interested in the subgroups of selfemployment in how they score in terms of satisfaction with life (and several domains in life). Until now, no distinction has been made in the life satisfaction literature between freelancers, other own-account workers and employers, despite the emergence of freelancers in developed economies.

We follow the bottom-up approach of life satisfaction (cf. Headey et al. 1991) and view life satisfaction as a function of satisfaction with several life (sub)domains (Erdogan et al. 2012). The domains under consideration are work, leisure, income and health. Indeed, the rationale is that individuals assess their satisfaction with the several domains such that they also end up with an "overall" cognitive evaluation of their lives.

To understand better the origin of subjective wellbeing differences between freelancers and other (selfemployed) workers, we provide an overview of the current literature in three steps. First, we discuss what is known about differences in subjective well-being between own-account workers and employers
(Section 2.1). Second, we zoom in on the group of freelancers (Section 2.2). Third, we provide a summary of existing insights and findings in which we formulate expectations about subjective well-being differences between own-account workers and employers, which helps us form expectations about subjective well-being differences between freelancers and other own-account workers (Section 2.3).

\subsection{Own-account workers versus employers}

Earlier research mainly focuses on the more general distinction between own-account workers (the selfemployed without employees) and employers (the selfemployed with employees). Indeed, this relatively broad distinction is common in entrepreneurship research. The employers are characterised by working under higher pressure (Blanchflower 2004) and having a higher workload with an additional set of tasks compared with own-account workers (Hébert and Link 1989; Lazear 2005), for example, because there is more coordination involved with their employees. In terms of autonomy, the self-employed with employees seem to be more autonomous regarding their decisions than ownaccount workers (Prottas and Thompson, 2006) because of the possibility of delegating work. At the same time, this autonomy is also under pressure because of the inability to have full control over the work that must be fulfilled (Hessels et al. 2017).

One could expect different satisfaction levels across the groups of own-account workers and employers. In terms of satisfaction with one's work there is earlier research suggesting that employers have higher work satisfaction levels than own-account workers (Hessels et al. 2015), but there are also studies finding nonsignificant differences in work satisfaction between the two groups (Prottas and Thompson, 2006; Beutell et al., 2014). The flexibility offered by own-account work has consequences in terms of the way in which own-account workers are able to balance their working with their nonworking life (Warr, 2018). Indeed, although limited empirical evidence exists, it could be expected that the own-account workers are more satisfied with their leisure time than employers.

There are also domains for which we expect lower satisfaction levels among own-account workers compared with employers. For example, in terms of satisfaction with pay and income satisfaction in general, we need to take into account the fact that there is 
earlier evidence of lower earnings among the ownaccount workers relative to employers (Sorgner et al. 2017). Hence, one would expect lower satisfaction levels among the own-account workers compared with employers in terms of the financial situation. Although we control for personal income (see Section 4), there are other aspects of income that could be relevant here, such as the variability and uncertainty of income and the income levels of other household members (we look at household income satisfaction). Regarding an individual's satisfaction with his/her health situation, we know from earlier literature that the self-employed tend to be healthier than wage workers (Rietveld et al. 2016) and that this is likely to be due to a selection effect of relatively healthier people selecting self-employment (Rietveld et al. 2015). It may be expected that being an employer requires a better health status due to the higher demands and lower flexibility if this selection effect argument is maintained. An alternative reasoning is that health may deteriorate resulting from experienced higher stress levels at work among employers (Hessels et al. 2017). Together with the fact that we control for subjective health status in our regressions (see Section 4) and given the very few earlier studies on the relationship with health satisfaction (Van der Zwan and Hessels, 2019) we abstain from formulating an expectation about how own-account workers and employers differ regarding their health satisfaction levels.

\subsection{Freelancers}

Van den Born and Van Witteloostuijn (2013) state that the emergence of freelancers corresponds with the prediction of Handy (1989) in that the organisation of the future consists of three types of workers: (1) professional employees, (2) professional freelancers, and (3) workers doing routine jobs. Van den Born and Van Witteloostuijn (2013) focus on a subjective measure of freelancers' career success, i.e. six items reflecting satisfaction with one's career. It turns out that autonomy, flexibility and work-life balance are significantly and positively related to subjective career success of freelancers. Indeed, Storey et al. (2005, p. 1050) conclude that "... freelancers tended to aspire to the core qualities of enterprise-independence and autonomy in their working lives." And (p. 1051): "There was the possibility of a more flexible, home-based working life for individuals with caring responsibilities or other personal commitments."

There is also a darker side of freelancing. "Termination" is a property inherently attached to freelance work which is temporary work by definition. This termination aspect poses financial risks to freelancers, and freelancers turn out to be concerned about their reputation (Storey et al. 2005). Although there is evidence that freelancers, on average, earn more than wage workers (Kunda et al. 2002), related to the fact that freelancers are highly-skilled (Burke 2015), there is also evidence of financial concerns (Storey et al. 2005) among freelancers, at least in specific sectors.

\subsection{Summary}

Taken all views on the existing literature together, it can be argued that existing research has been silent on how subjective well-being levels of freelancers compare with other self-employed workers and wage workers. In general, the group of own-account workers - which incorporates freelancers - have been shown to be less satisfied with their work than employers or score similarly in terms of work satisfaction as employers, and it is expected that own-account workers are more satisfied with their leisure time than employers (based on Section 2.1). In terms of the financial situation, the own-account workers are expected to score worse than employers, while for life satisfaction - for which mixed empirical evidence exists (Van der Zwan and Hessels, 2019) — and health satisfaction no expectations can be formulated a priori (also based on Section 2.1).

Given the importance of autonomy, flexibility and work-life balance for the group of freelancers (Section 2.2), it can be expected that freelancers score higher in terms of work satisfaction and leisure satisfaction than other own-account workers. In terms of the financial situation, the argument that freelancers are "... high earner and high skilled workers..." (Burke 2015, p. vii) suggests that they score better than other own-account workers, even though there is also financial uncertainty within this group (Storey et al. 2005), which could be related to the uncertainty and variability of income levels. We abstain from formulating expectations about differences between freelancers and other own-account workers in terms of satisfaction with health and life. 


\section{Data and methodology}

\subsection{Data}

We use data from the UK Household Longitudinal Study (UKHLS; "Understanding Society") which started as a longitudinal study in the UK among 40,000 households in 2009. Six waves of data in the period 2009-2015 are used. The UKHLS is the successor of the frequently used British Household Panel Survey (BHPS). Respondents who were still active at the eighteenth wave of BHPS were transformed to the second wave of UKHLS. The geographical areas of England, Northern Ireland, Scotland and Wales are represented in the UKHLS. For the first five waves, the sample is representative of people who had lived continuously in the UK since 2009. For the sixth wave, the sample is representative of people who had lived continuously in the UK since 2014 . We restrict our sample to individuals of 16 years of age or older. Detailed sample information, such as in terms of sample design, data collection details and questionnaire information, is provided in Lynn (2009) and Knies (2016).

The dataset is useful for the present study because (1) it contains detailed self-employment information in that we can distinguish between freelancers, other ownaccount workers and employers; (2) it contains data on wage workers such that we can compare subjective well-being levels of freelancers with this comparison group; (3) the data are recent (from 2009 to 2015) such that this dataset addresses the recent upsurge of freelancing; (4) the data are available for various years such that the results are not driven by a single year, and we can investigate variation within individuals over time; and (5) the dataset enables an inspection of the potential mechanisms behind different life satisfaction levels between occupational groups because it includes a wide array of satisfaction variables.

\subsection{Variables}

There exist various definitions of freelancers, for example in terms of skills and occupations, but in the present paper we use a self-assessment of respondents. In a more detailed fashion, respondents are first asked whether they are (1) a wage worker or (2) selfemployed. This refers to the respondent's main job; his/her second job is not taken into account. In a follow-up question, the self-employed are requested to answer whether they have employees or not, and whether they are (1) doing freelance work or (2) involved in another self-employment activity (e.g. running a business or professional practise, working for themselves, being a sub-contractor or being self-employed in some other way). Taking all answers together, we create a variable with four values in total: value 0 for freelancers, 1 for other own-account workers, 2 for employers, and 3 for wage workers. Individuals who are working in a partnership with someone else are not taken into account in the analyses. ${ }^{3}$

Life satisfaction is measured with the following item (Ambrey and Fleming 2014): "How dissatisfied or satisfied are you with your life overall?" Earlier studies on self-employment and life satisfaction have used a similar single-item measure. The single-item measures perform well compared with the more psychometrically established Satisfaction with Life Scale of Diener et al. (1985) (Schimmack and Oishi 2005; Cheung and Lucas 2014). The answers are given on a 7-point scale that ranges from completely dissatisfied (value 1) to completely satisfied (value 7). In addition, an individual's satisfaction with the job is retrieved ("How dissatisfied or satisfied are you with your present job overall?), again on a 7-point scale. Similar satisfaction questions are asked for "... the amount of leisure time you have", "... the income of your household", and "... your health". For all satisfaction measures, it holds that larger values indicate more satisfied individuals.

\subsection{Methodology}

The first step of our multivariate analysis is to use life satisfaction as the dependent variable and the employment variable (see above) as the independent variable. In this way, we can see how freelancers compare with other own-account workers, employers and wage workers in terms of life satisfaction.

As a second step, we treat the other satisfaction variables as dependent variables (work, leisure, income, health), and this provides us with information for which domains of satisfaction freelancers score differently than other own-account workers, employers and wage workers.

\footnotetext{
$\overline{{ }^{3} \text { Our regression }}$ specification is robust to the inclusion of entrepreneurial endeavours in teams/partnerships.
} 
We control for several individual-level determinants of life satisfaction, as suggested by the literature review of Dolan et al. (2008). The control variables are gender (male $=1$; female $=0$ ), age and age squared $(16+)$, education (highest qualification is at least higher education $=1 ; 0$ otherwise), marital status (single or never married, married, separated/divorced/widowed), whether there are children living at home (yes $=1$; no $=0$ ), number of working hours per week, ${ }^{4}$ income (an individual's net monthly income from employment, logarithmically transformed); industry (SIC 1 codes; 17 industries in total), health status ("In general, would you say your health is excellent, very good, good, fair, or poor?", geographical region (England, Northern Ireland, Scotland, Wales) and wave number (wave 1 to 6$)^{5}$

We perform ordinary least squares regressions to model our dependent variables with values 1 to 7 . Ordered probit regressions have been performed as well as a robustness specification, but this does not lead to qualitatively different conclusions (these results are available from the authors upon request). In the satisfaction literature, there has been a debate about treating the satisfaction variables as cardinal or ordinal variables, but in general conclusions do not seem to be very different between the two approaches (Ferrer-iCarbonell and Frijters 2004). In addition, the straightforward interpretation is a great benefit of ordinary least squares regressions. In a second analysis, we make use of the panel data structure of the dataset. That is, we perform linear fixed-effects regressions that exploit the variation within individuals (over time). ${ }^{6}$ In all our analyses standard errors are clustered at the individual.

\section{Results}

\subsection{Descriptive statistics}

First, we show some descriptive statistics on the prevalence of freelancers, both as a percentage of the own-

\footnotetext{
${ }^{4}$ There is empirical evidence for an inverse U-shaped relationship between the number of working hours and subjective well-being. We abstained from including a quadratic term of number of working hours because we could not verify such an inverse U-shaped relationship in our data.

${ }^{5}$ Age and number of working hours have been divided by 10 in our regression analysis to reduce the number of noughts behind the decimal point of the estimated coefficients.

${ }^{6}$ Hausman tests reveal that a fixed-effects specification is preferred to a random-effects specification for each dependent variable $(p<0.001)$.
}

account workers and as a percentage of the total group of self-employed workers. We note that our sample contains 1,432 freelancers, 10,434 other own-account workers, 1,478 employers and 115,336 wage workers (estimation sample consists of 128,680 year-person observations in total, for 41,109 individuals). Hence, freelancers represent about $11 \%$ of the total group of selfemployed workers. This percentage is lower than the percentages as found by Kitching (2015), for roughly the same geographical region. However, the definitions of freelancing activities differ between the two studies: while Kitching (2015) uses a classification based on occupation and skills, we use a self-assessment criterion in the present paper. Kitching and Smallbone (2012) show that a self-assessment criterion may lead to an underestimate of the group of freelancers (while also a classification based on occupational groups and skill levels is far from perfect).

In Table 1, we undertake a first attempt of comparing the several groups of self-employed workers and wage workers on the basis of the satisfaction variables and individual-level control variables that will be included in the multivariate analyses below. Column 1 focuses on freelancers, column 2 on the other own-account workers, column 3 on the employers and column 4 on the wage workers. We conclude from Table 1 that the freelancer group constitutes a separate group, even compared with the other own-account workers. That is, freelancers turn out to be more satisfied with their lives (5.22) than the other own-account workers (5.16) and about equally satisfied as employers (5.23). The differences are not significant across the four groups. The work satisfaction levels of the freelancers (5.56) are significantly lower than the satisfaction levels of employers $(5.84 ; p<0.001)$, but substantially higher than those of the wage workers $(5.27 ; p<0.001)$. Substantial differences are found between freelancers and the other employment groups in terms of leisure satisfaction. That is, freelancers turn out to be substantially more satisfied with their leisure time (4.79) than the other own-account workers $(4.50 ; p<0.001)$, employers $(4.16 ; p<0.001)$ and wage workers $(4.40 ; p<0.001)$. In terms of income satisfaction, freelancers are significantly less satisfied (4.51) than employers $(4.67 ; p=0.05)$. Freelancers are most satisfied with their health (4.97) across the four employment groups, but the differences are not significant. Hence, these descriptive statistics already provide an interesting view in that freelancers turn out to arrive at life satisfaction levels that are not significantly lower 
than the levels of the remaining employment groups. Some noteworthy differences are found for the other satisfaction variables. That is, work satisfaction levels are relatively low but leisure satisfaction levels are relatively high among the freelancers compared with other self-employed workers.

The image of freelancers as highly skilled professionals or knowledge workers can be confirmed in Table 1. The share of freelancers that is highly educated is much larger compared with the other self-employed groups (in both cases $p<0.001$ ) and also compared with the wage workers $(p<0.001)$. Furthermore, there are four sectors in our dataset in which freelancers are much more likely to be active than the other own-account workers: information and communication (16\% versus $4 \% ; p<0.001)$; professional, scientific and technical activities $(20 \%$ versus $10 \%$; $p<0.001)$; arts, entertainment and recreation $(13 \%$ versus $3 \% ; p<0.001)$; and education $(13 \%$ versus $8 \% ; p<0.001)$. Also, employers have a relatively low likelihood of being active in these sectors (2\% for information and communication, $11 \%$ for professional activities, $3 \%$ for arts, entertainment and recreation, and $4 \%$ for education). Finally, employers are much more likely than freelancers to be active in wholesale and retail trade (16\% versus $4 \%$; $p<0.001$ ), construction (15\% versus $4 \% ; p<0.001$ ), food services (9\% versus $1 \% ; p<0.001)$ and agriculture and mining ( $4 \%$ versus $1 \% ; p<0.001)$.

\subsection{Multivariate analysis}

\subsubsection{OLS regressions}

Table 2 shows the results of ordinary least squares (OLS) regressions. ${ }^{7}$ In column 1 , life satisfaction is the dependent variable, while columns 2 to 5 proceed with satisfaction with work, leisure time, income and health. Dummy (1/0) variables for the employment groups are included in the regressions with freelancing as the reference category. Hence, interpretation of the coefficients of the variables representing the other own-account workers, employers and wage workers has to be done relative to the group of freelancers.

The results in column 1 of Table 2 reveal that freelancers have similar life satisfaction levels as the other own-account workers $(p=0.79)$, employers $(p=0.38)$

\footnotetext{
${ }^{7}$ There are no concerns for multicollinearity because of the absence of excessive correlation coefficients for our set of control variables.
}

and wage workers $(p=0.60)$. An additional Wald test reveals (not displayed; $p=0.38$ ) that employers are not more satisfied with their lives than the other ownaccount workers.

In terms of work satisfaction in column 2, some striking differences exist. Freelancers are significantly less satisfied with their work than the other own-account workers $(p=0.05)$ and the employers $(p<0.001)$. Clearly, freelancers are significantly more satisfied with their work than wage workers $(p<0.001)$. Note that the satisfaction difference between freelancers and other ownaccount workers $(0.083)$ is small compared with the satisfaction difference between freelancers and employers (0.300). Unsurprisingly, a Wald test reveals that employers are significantly more satisfied with their work than other own-account workers $(p<0.001)$.

Column 3 of Table 2 reveals that freelancers are clearly a separate group when it concerns leisure time. That is, freelancers are significantly more satisfied with their leisure time than other own-account workers ( $p=$ $0.04)$, employers $(p<0.001)$ and wage workers $(p<0.001)$. It is expected that freelancers are better able to combine their working life with their non-working or family life because of the flexibility they experience, but we do not have an appropriate measure of work-life balance to validate this. We observe that employers are significantly less satisfied with their leisure time than the other own-account workers (Wald test; $p=0.01$ ).

Freelancers are significantly less satisfied with their household income than employers (see column 4 of Table $2(p<0.001))$. Also the other own-account workers are significantly less satisfied with their income than employers (a Wald test results in $p=0.002$ (nonreported)). No statistically significant differences in terms of income satisfaction are found between freelancers on the one hand and other own-account workers $(p=0.21)$ and wage workers $(p=0.17)$ on the other hand. The results in column 5 of Table 2 reveal that there are no significant differences in terms of health satisfaction across the board $(p=0.37$ for own-account workers, $p=0.29$ for employers, $p=0.70$ for wage workers). ${ }^{8}$

\footnotetext{
${ }^{8}$ When merging the freelancers and other own-account workers the OLS regressions reveal that there are no significant differences between this total group of own-account workers and employers in terms of life $(p=0.36)$ and health satisfaction $(p=0.52)$. Employers experience significantly more work $(p<0.001)$ and income satisfaction $(p<0.001)$, and significantly less leisure satisfaction $(p=0.01)$.
} 
Table 1 Minimum, maximum and average values for dependent and control variables across the employment groups

\begin{tabular}{|c|c|c|c|c|c|c|}
\hline & Min. & Max. & $\begin{array}{l}\text { (1) } \\
\text { Freelancers }\end{array}$ & $\begin{array}{l}(2) \\
\text { Other own-account } \\
\text { workers }\end{array}$ & $\begin{array}{l}(3) \\
\text { Employers }\end{array}$ & $\begin{array}{l}\text { (4) } \\
\text { Wage workers }\end{array}$ \\
\hline Life satisfaction & 1 & 7 & 5.22 & 5.16 & 5.23 & 5.20 \\
\hline Work satisfaction & 1 & 7 & 5.56 & 5.61 & $5.84 *$ & $5.27 *$ \\
\hline Leisure satisfaction & 1 & 7 & 4.79 & $4.50^{*}$ & $4.16^{*}$ & $4.40^{*}$ \\
\hline Income satisfaction & 1 & 7 & 4.51 & 4.39 & $4.67^{*}$ & 4.53 \\
\hline Health satisfaction & 1 & 7 & 4.97 & 4.86 & 4.90 & 4.89 \\
\hline Gender $($ male $=1 ;$ female $=0)$ & 0 & 1 & 0.54 & $0.65^{*}$ & $0.73^{*}$ & $0.44 *$ \\
\hline Age & 16 & 88 & 47.22 & 46.89 & 48.06 & $41.05^{*}$ \\
\hline Education (higher education $=1 ;$ otherwise $=0$ ) & 0 & 1 & 0.70 & $0.39 *$ & $0.40^{*}$ & $0.44 *$ \\
\hline \multicolumn{7}{|l|}{ Marital status } \\
\hline Single/never married ${ }^{\#}$ & 0 & 1 & 0.36 & $0.29 *$ & $0.21 *$ & 0.38 \\
\hline Married & 0 & 1 & 0.52 & $0.61 *$ & $0.69^{*}$ & 0.53 \\
\hline Separated/divorced/widowed & 0 & 1 & 0.11 & 0.10 & 0.09 & $0.09^{*}$ \\
\hline Children at home $($ yes $=1 ;$ no $=0$ ) & 0 & 1 & 0.29 & $0.37^{*}$ & $0.40^{*}$ & $0.37^{*}$ \\
\hline Weekly working hours & 1 & 120 & 27.09 & $34.26^{*}$ & $45.25^{*}$ & $32.25^{*}$ \\
\hline Log monthly net income & -4.61 & 9.62 & 6.59 & $6.63^{*}$ & $7.14 *$ & $7.03 *$ \\
\hline \multicolumn{7}{|l|}{ Health } \\
\hline Poor $^{\#}$ & 0 & 1 & 0.02 & 0.02 & 0.01 & 0.02 \\
\hline Fair & 0 & 1 & 0.09 & 0.10 & 0.09 & 0.09 \\
\hline Good & 0 & 1 & 0.26 & $0.30^{*}$ & 0.27 & 0.28 \\
\hline Very good & 0 & 1 & 0.39 & 0.38 & 0.39 & 0.40 \\
\hline Excellent & 0 & 1 & 0.25 & $0.21 *$ & 0.23 & $0.21^{*}$ \\
\hline \multicolumn{7}{|l|}{ Region } \\
\hline England $^{\#}$ & 0 & 1 & 0.82 & 0.81 & $0.76^{*}$ & $0.78^{*}$ \\
\hline Northern Ireland & 0 & 1 & 0.03 & 0.06 & 0.08 & 0.06 \\
\hline Scotland & 0 & 1 & 0.09 & 0.07 & 0.08 & 0.09 \\
\hline Wales & 0 & 1 & 0.06 & $0.06^{*}$ & $0.08 *$ & $0.07^{*}$ \\
\hline \multicolumn{7}{|l|}{ Sector } \\
\hline Administrative/support & 0 & 1 & 0.06 & $0.08 *$ & 0.06 & $0.04 *$ \\
\hline Agriculture/mining & 0 & 1 & 0.01 & $0.03 *$ & $0.04 *$ & 0.01 \\
\hline Arts/entertainment/recreation & 0 & 1 & 0.13 & $0.03 *$ & $0.03^{*}$ & $0.02 *$ \\
\hline Construction & 0 & 1 & 0.04 & $0.21 *$ & $0.15^{*}$ & 0.04 \\
\hline Education & 0 & 1 & 0.13 & $0.08 *$ & $0.04 *$ & 0.12 \\
\hline Electricity/water & 0 & 1 & 0.01 & 0.00 & 0.00 & 0.01 \\
\hline Finance/insurance & 0 & 1 & 0.02 & 0.02 & 0.02 & $0.04 *$ \\
\hline Food services & 0 & 1 & 0.01 & 0.01 & $0.09^{*}$ & $0.05^{*}$ \\
\hline Health & 0 & 1 & 0.06 & 0.09 & 0.08 & $0.18^{*}$ \\
\hline Information/communication & 0 & 1 & 0.16 & $0.04 *$ & $0.02 *$ & $0.03 *$ \\
\hline Manufacturing $^{\#}$ & 0 & 1 & 0.04 & 0.04 & 0.07 & $0.10^{*}$ \\
\hline Other services & 0 & 1 & 0.04 & $0.09 *$ & $0.07 *$ & $0.02 *$ \\
\hline Professional/scientific/technical & 0 & 1 & 0.20 & $0.10^{*}$ & $0.11^{*}$ & $0.05^{*}$ \\
\hline Public administration & 0 & 1 & 0.01 & 0.00 & 0.00 & $0.08 *$ \\
\hline Real estate & 0 & 1 & 0.00 & 0.01 & $0.01 *$ & $0.01 *$ \\
\hline Transport & 0 & 1 & 0.03 & $0.08 *$ & 0.04 & $0.04 *$ \\
\hline Wholesale and retail trade & 0 & 1 & 0.04 & $0.08 *$ & $0.16^{*}$ & $0.14 *$ \\
\hline
\end{tabular}

\# Reference category in the multivariate analysis. Min., minimum value in the estimation sample; Max., maximum value in the estimation sample. The wave variables have been omitted from this table (but included in our multivariate analysis)

*Indicates a significant difference $(p<0.05)$ with the freelancers 


\subsubsection{Fixed-effects}

We perform a panel-data fixed-effects regression that explores the variation over time within individuals. An additional benefit of this analysis is that unobserved time-invariant variables are controlled for ("differenced away"). ${ }^{9}$ The results are shown in Table 3.

For life satisfaction, we draw the same conclusion as in Table 2: no significant differences are found between the three employment groups $(p=0.11$ for own-account work, $p=0.41$ for employership, $p=0.11$ for wage work). Importantly, for work and income satisfaction, no significant differences are detected between freelancing and other own-account work ( $p=0.27$ for work, $p=0.11$ for income) and between freelancing and employership ( $p=0.50$ for work, $p=0.90$ for income). For leisure satisfaction, we again find significantly higher satisfaction levels for freelancing than other own-account work $(p=0.02)$, employership $(p<0.001)$ and wage work $(p<0.001)$. Finally, freelancing is associated with significantly more satisfaction with health than wage work in this fixed-effects specification $(p=0.01){ }^{10}$

\subsection{Additional analyses}

Possible drivers behind work and leisure satisfaction differences The dataset contains an array of job autonomy variables, i.e. the influence one has over the tasks in the job, the work pace, how to do the work, the order in which to carry out tasks and in terms of working hours. For each variable, it holds that employers have the highest level of autonomy, followed by the other ownaccount workers, the freelancers and the wage workers (results not shown). Hence, a reason why employers are more satisfied with their work than freelancers may be because of their higher experienced level of autonomy. In addition, we are able to compare freelancers and the

\footnotetext{
${ }^{9}$ The gender variable is therefore not included in this fixed-effects specification. We also excluded the education and region variables due to minimal within-variation. Note that both the linear age variable and the five wave dummy variables are included in Table 3; the reason is that an individual's age does not always increase by one year in consecutive waves because of the different moments in a calendar year when surveys have been conducted.

${ }^{10}$ When merging the freelancers and other own-account workers, the fixed-effects regressions reveal that employers experience significantly less leisure satisfaction than own-account workers $(p=0.01)$; there are no significant differences for the other satisfaction variables between the two groups $(p=0.69$ for life, $p=0.87$ for work, $p=0.59$ for income, $p=0.18$ for health).
}

other self-employed workers and wage workers in terms of the flexibility and work rhythm they experience at work. Two observations stand out. First, freelancers are most likely to work from home among all employment groups. Second, freelancers are least likely to report that they have a fixed schedule to perform their work. Hence, the increased flexibility may be behind the leisure satisfaction differences as found in our multivariate analysis. $^{11}$

Importance of life domains We add the satisfaction variables for the four subdomains (work, leisure, income, health) to the life satisfaction regression in column 1 of Table 3 (results not tabulated). Again, we find non-significant coefficients for our employment dummy variables ( $p=0.55$ for own-account workers, $p=0.78$ for employers, $p=0.22$ for wage workers). Interaction terms between the satisfaction variables and our employment dummy variables are included as well. This answers the question whether the life domains weigh differently regarding their importance for overall satisfaction with life. In general, there are no differences across the employment groups in terms of the importance of the life domains (work, leisure, income, health) in the determination of life satisfaction. Hence, freelancers attach equal importance to the several domains when evaluating their overall satisfaction with life compared with the other own-account workers, employers and wage workers. ${ }^{12}$

Other dataset Larger datasets with information on freelancers that could verify our results in other countries than the UK are difficult to obtain. We use Australian longitudinal data (2001-2013; HILDA) to compare own-account workers (including freelancers) with employers and wage workers. There are again no significant differences in life satisfaction between ownaccount workers, employers and wage workers (results not tabulated). Own-account workers are, however, significantly more satisfied with their leisure time and work-life balance (Anxo and Ericson 2015) than employers. This is an interesting result because with the present UK dataset we do not have access to a measure of work-life balance.

\footnotetext{
$\overline{{ }^{11} \text { Unfortunately, }}$ these autonomy and flexibility measures are not available for all waves.

${ }^{12}$ There is one exception: income satisfaction weighs less heavily in the determination of life satisfaction for wage workers than for freelancers $(\beta=-0.05 ; p=0.22)$.
} 
Table 2 OLS regressions with satisfaction with life, work, leisure time, income and health as dependent variables

\begin{tabular}{|c|c|c|c|c|c|}
\hline & $\begin{array}{l}(1) \\
\text { Life }\end{array}$ & $\begin{array}{l}(2) \\
\text { Work }\end{array}$ & $\begin{array}{l}(3) \\
\text { Leisure }\end{array}$ & $\begin{array}{l}\text { (4) } \\
\text { Income }\end{array}$ & $\begin{array}{l}\text { (5) } \\
\text { Health }\end{array}$ \\
\hline \multicolumn{6}{|c|}{ Employment (reference: "freelancers") } \\
\hline Other own-account workers & $\begin{array}{l}0.011 \\
(0.043)\end{array}$ & $\begin{array}{l}0.083^{*} \\
(0.042)\end{array}$ & $\begin{array}{l}-0.105^{*} \\
(0.051)\end{array}$ & $\begin{array}{l}0.066 \\
(0.054)\end{array}$ & $\begin{array}{c}-0.040 \\
(0.044)\end{array}$ \\
\hline Employers & $\begin{array}{l}0.052 \\
(0.060)\end{array}$ & $\begin{array}{l}0.300 * * * \\
(0.059)\end{array}$ & $\begin{array}{l}-0.244 * * * \\
(0.070)\end{array}$ & $\begin{array}{l}0.231 * * \\
(0.071)\end{array}$ & $\begin{array}{l}-0.067 \\
(0.063)\end{array}$ \\
\hline Wage workers & $\begin{array}{l}0.022 \\
(0.041)\end{array}$ & $\begin{array}{l}-0.222^{* * *} \\
(0.040)\end{array}$ & $\begin{array}{l}-0.188^{* * * *} \\
(0.050)\end{array}$ & $\begin{array}{l}0.070 \\
(0.052)\end{array}$ & $\begin{array}{c}-0.017 \\
(0.042)\end{array}$ \\
\hline Gender & $\begin{array}{l}-0.035^{* *} \\
(0.012)\end{array}$ & $\begin{array}{l}-0.117 * * * \\
(0.013)\end{array}$ & $\begin{array}{l}0.164 * * * \\
(0.014)\end{array}$ & $\begin{array}{l}-0.055^{* * * *} \\
(0.015)\end{array}$ & $\begin{array}{l}0.041 * * * \\
(0.012)\end{array}$ \\
\hline $\mathrm{Age}^{\#}$ & $\begin{array}{l}-0.604 * * * \\
(0.027)\end{array}$ & $\begin{array}{l}-0.467^{* * *} \\
(0.028)\end{array}$ & $\begin{array}{l}-0.393 * * * \\
(0.031)\end{array}$ & $\begin{array}{l}-0.810^{* * *} \\
(0.033)\end{array}$ & $\begin{array}{l}-0.327^{* * * *} \\
(0.027)\end{array}$ \\
\hline Age squared ${ }^{\#}$ & $\begin{array}{l}0.071 * * * \\
(0.003)\end{array}$ & $\begin{array}{l}0.061 * * * \\
(0.003)\end{array}$ & $\begin{array}{l}0.053 * * * \\
(0.004)\end{array}$ & $\begin{array}{l}0.099 * * * \\
(0.004)\end{array}$ & $\begin{array}{l}0.039 * * * \\
(0.003)\end{array}$ \\
\hline Education & $\begin{array}{l}0.032 * * \\
(0.011)\end{array}$ & $\begin{array}{l}-0.102 * * * \\
(0.012)\end{array}$ & $\begin{array}{l}-0.029 * \\
(0.013)\end{array}$ & $\begin{array}{l}0.148^{* * * *} \\
(0.014)\end{array}$ & $\begin{array}{l}0.046^{* * * *} \\
(0.012)\end{array}$ \\
\hline \multicolumn{6}{|l|}{ Marital status (reference: "single") } \\
\hline Married & $\begin{array}{l}0.203 * * * \\
(0.014)\end{array}$ & $\begin{array}{l}0.112 * * * \\
(0.015)\end{array}$ & $\begin{array}{l}0.045 * * \\
(0.015)\end{array}$ & $\begin{array}{l}0.228 * * * \\
(0.016)\end{array}$ & $\begin{array}{l}0.058 * * * \\
(0.014)\end{array}$ \\
\hline Separated/divorced/widowed & $\begin{array}{l}-0.183^{* * *} \\
(0.022)\end{array}$ & $\begin{array}{l}0.062 * * \\
(0.023)\end{array}$ & $\begin{array}{l}-0.024 \\
(0.024)\end{array}$ & $\begin{array}{l}-0.304 * * * \\
(0.026)\end{array}$ & $\begin{array}{l}-0.015 \\
(0.021)\end{array}$ \\
\hline Children at home & $\begin{array}{l}-0.004 \\
(0.012)\end{array}$ & $\begin{array}{l}0.068 * * * \\
(0.013)\end{array}$ & $\begin{array}{l}-0.328^{* * *} \\
(0.014)\end{array}$ & $\begin{array}{l}-0.240 \text { *** } \\
(0.015)\end{array}$ & $\begin{array}{l}-0.035^{* *} \\
(0.013)\end{array}$ \\
\hline Weekly working hours ${ }^{\#}$ & $\begin{array}{l}-0.033^{* * *} \\
(0.005)\end{array}$ & $\begin{array}{l}-0.016^{* *} \\
(0.005)\end{array}$ & $\begin{array}{l}-0.205^{* * *} \\
(0.006)\end{array}$ & $\begin{array}{l}-0.061 \text { *** } \\
(0.006)\end{array}$ & $\begin{array}{l}-0.002 \\
(0.005)\end{array}$ \\
\hline Log monthly net income & $\begin{array}{l}0.078 * * * \\
(0.008)\end{array}$ & $\begin{array}{l}0.045^{* * * *} \\
(0.008)\end{array}$ & $\begin{array}{l}-0.002 \\
(0.009)\end{array}$ & $\begin{array}{l}0.285^{* * * *} \\
(0.010)\end{array}$ & $\begin{array}{l}0.009 \\
(0.008)\end{array}$ \\
\hline \multicolumn{6}{|l|}{ Health (reference: "poor") } \\
\hline Fair & $\begin{array}{l}0.559 * * * \\
(0.042)\end{array}$ & $\begin{array}{l}0.218^{* * *} \\
(0.047)\end{array}$ & $\begin{array}{l}0.235^{* * *} \\
(0.040)\end{array}$ & $\begin{array}{l}0.384 * * * \\
(0.044)\end{array}$ & $\begin{array}{l}1.185^{* * *} \\
(0.034)\end{array}$ \\
\hline Good & $\begin{array}{l}1.021 * * * \\
(0.041)\end{array}$ & $\begin{array}{l}0.473 * * * \\
(0.047)\end{array}$ & $\begin{array}{l}0.599 * * * \\
(0.039)\end{array}$ & $\begin{array}{l}0.795 * * * \\
(0.044)\end{array}$ & $\begin{array}{l}2.104 * * * \\
(0.033)\end{array}$ \\
\hline Very good & $\begin{array}{l}1.332^{* * * *} \\
(0.041)\end{array}$ & $\begin{array}{l}0.670^{* * * *} \\
(0.047)\end{array}$ & $\begin{array}{l}0.907 * * * \\
(0.039)\end{array}$ & $\begin{array}{l}1.143^{* * * *} \\
(0.044)\end{array}$ & $\begin{array}{l}2.739 * * * \\
(0.033)\end{array}$ \\
\hline Excellent & $\begin{array}{l}1.557 * * * \\
(0.042)\end{array}$ & $\begin{array}{l}0.827 * * * \\
(0.047)\end{array}$ & $\begin{array}{l}1.153 * * * \\
(0.040)\end{array}$ & $\begin{array}{l}1.375^{* * *} \\
(0.045)\end{array}$ & $\begin{array}{l}3.180 * * * \\
(0.035)\end{array}$ \\
\hline \multicolumn{6}{|l|}{ Region (reference: "England") } \\
\hline Northern Ireland & $\begin{array}{l}0.139 * * * \\
(0.020)\end{array}$ & $\begin{array}{l}0.098 * * * \\
(0.022)\end{array}$ & $\begin{array}{l}0.220 * * * \\
(0.024)\end{array}$ & $\begin{array}{l}0.108^{* * * *} \\
(0.025)\end{array}$ & $\begin{array}{l}0.031 \\
(0.022)\end{array}$ \\
\hline Scotland & $\begin{array}{l}0.001 \\
(0.018)\end{array}$ & $\begin{array}{l}-0.017 \\
(0.020)\end{array}$ & $\begin{array}{l}0.057 * * \\
(0.021)\end{array}$ & $\begin{array}{l}0.004 \\
(0.022)\end{array}$ & $\begin{array}{l}-0.095^{* * * *} \\
(0.019)\end{array}$ \\
\hline Wales & $\begin{array}{l}0.026 \\
(0.021)\end{array}$ & $\begin{array}{l}0.041 \\
(0.023)\end{array}$ & $\begin{array}{l}0.006 \\
(0.024)\end{array}$ & $\begin{array}{l}-0.061^{*} \\
(0.025)\end{array}$ & $\begin{array}{l}-0.067 * * \\
(0.022)\end{array}$ \\
\hline \multicolumn{6}{|c|}{ Sector (reference: "manufacturing") } \\
\hline Administrative/support & $\begin{array}{l}-0.132 * * * \\
(0.029)\end{array}$ & $\begin{array}{l}-0.091^{* *} \\
(0.032)\end{array}$ & $\begin{array}{l}-0.143^{* * *} \\
(0.034)\end{array}$ & $\begin{array}{l}-0.236^{* * * *} \\
(0.035)\end{array}$ & $\begin{array}{l}-0.051 \\
(0.030)\end{array}$ \\
\hline Agriculture/mining & $\begin{array}{l}0.117^{*} \\
(0.051)\end{array}$ & $\begin{array}{l}0.310^{* * *} \\
(0.049)\end{array}$ & $\begin{array}{l}0.242 * * * \\
(0.059)\end{array}$ & $\begin{array}{l}0.140^{*} \\
(0.060)\end{array}$ & $\begin{array}{l}0.096 \\
(0.055)\end{array}$ \\
\hline Arts/entertainment/recreation & $\begin{array}{l}-0.076^{*} \\
(0.037)\end{array}$ & $\begin{array}{l}0.081^{*} \\
(0.039)\end{array}$ & $\begin{array}{l}-0.132 * * \\
(0.042)\end{array}$ & $\begin{array}{l}-0.187 \text { *** } \\
(0.045)\end{array}$ & $\begin{array}{l}-0.090 * \\
(0.038)\end{array}$ \\
\hline Construction & $\begin{array}{l}0.018 \\
(0.028)\end{array}$ & $\begin{array}{l}0.051 \\
(0.031)\end{array}$ & $\begin{array}{l}-0.038 \\
(0.032)\end{array}$ & $\begin{array}{l}-0.090^{* *} \\
(0.033)\end{array}$ & $\begin{array}{l}-0.003 \\
(0.028)\end{array}$ \\
\hline Education & -0.011 & $0.192 * * *$ & $-0.062 *$ & -0.021 & -0.026 \\
\hline
\end{tabular}


Table 2 (continued)

\begin{tabular}{|c|c|c|c|c|c|}
\hline & $\begin{array}{l}(1) \\
\text { Life }\end{array}$ & $\begin{array}{l}(2) \\
\text { Work }\end{array}$ & $\begin{array}{l}(3) \\
\text { Leisure }\end{array}$ & $\begin{array}{l}(4) \\
\text { Income }\end{array}$ & $\begin{array}{l}\text { (5) } \\
\text { Health }\end{array}$ \\
\hline & $(0.023)$ & $(0.025)$ & $(0.028)$ & $(0.028)$ & $(0.024)$ \\
\hline \multirow[t]{2}{*}{ Electricity/water } & -0.030 & -0.044 & -0.069 & -0.069 & -0.051 \\
\hline & $(0.044)$ & $(0.057)$ & $(0.054)$ & $(0.055)$ & $(0.048)$ \\
\hline \multirow[t]{2}{*}{ Finance/insurance } & -0.052 & $-0.151 * * *$ & $-0.078^{*}$ & 0.018 & $-0.080^{*}$ \\
\hline & $(0.030)$ & $(0.035)$ & $(0.037)$ & $(0.039)$ & $(0.032)$ \\
\hline \multirow[t]{2}{*}{ Food services } & $-0.152 * * *$ & -0.043 & $-0.219 * * *$ & $-0.175^{* * *}$ & -0.041 \\
\hline & $(0.028)$ & $(0.031)$ & $(0.032)$ & $(0.034)$ & $(0.029)$ \\
\hline \multirow[t]{2}{*}{ Health } & $-0.044^{*}$ & $0.090^{* * *}$ & $-0.057^{*}$ & $-0.143^{* * *}$ & -0.038 \\
\hline & $(0.022)$ & $(0.024)$ & $(0.025)$ & $(0.026)$ & $(0.022)$ \\
\hline \multirow[t]{2}{*}{ Information/communication } & -0.045 & -0.008 & $-0.103^{* *}$ & 0.026 & $-0.120 * * *$ \\
\hline & $(0.031)$ & $(0.035)$ & $(0.037)$ & $(0.038)$ & $(0.032)$ \\
\hline \multirow[t]{2}{*}{ Other services } & -0.010 & $0.329 * * *$ & $-0.139 * * *$ & $-0.099^{*}$ & -0.053 \\
\hline & $(0.035)$ & $(0.036)$ & $(0.041)$ & $(0.043)$ & $(0.036)$ \\
\hline \multirow[t]{2}{*}{ Professional/scientific/technical } & $-0.062 *$ & $0.082 * *$ & $-0.123 * * *$ & $-0.096^{* *}$ & $-0.066^{*}$ \\
\hline & $(0.027)$ & $(0.029)$ & $(0.032)$ & $(0.033)$ & $(0.028)$ \\
\hline \multirow[t]{2}{*}{ Public administration } & -0.007 & $-0.139^{* * *}$ & 0.027 & -0.023 & $-0.073 * *$ \\
\hline & $(0.025)$ & $(0.029)$ & $(0.030)$ & $(0.030)$ & $(0.026)$ \\
\hline \multirow[t]{2}{*}{ Real estate } & -0.096 & 0.034 & $-0.126^{*}$ & -0.086 & -0.041 \\
\hline & $(0.056)$ & $(0.058)$ & $(0.061)$ & $(0.065)$ & $(0.055)$ \\
\hline \multirow[t]{2}{*}{ Transport } & $-0.150 * * *$ & $-0.138^{* * *}$ & $-0.167 * * *$ & $-0.186^{* * *}$ & $-0.068^{*}$ \\
\hline & $(0.029)$ & $(0.034)$ & $(0.034)$ & $(0.034)$ & $(0.030)$ \\
\hline \multirow[t]{2}{*}{ Wholesale and retail trade } & $-0.130^{* * *}$ & $-0.067 * *$ & $-0.179 * * *$ & $-0.177 * * *$ & $-0.056^{*}$ \\
\hline & $(0.022)$ & $(0.025)$ & $(0.026)$ & $(0.026)$ & $(0.023)$ \\
\hline \multicolumn{6}{|l|}{ Wave (reference: "wave 1") } \\
\hline \multirow[t]{2}{*}{ Wave 2} & $-0.050 * * *$ & -0.006 & $-0.035^{* *}$ & -0.005 & $-0.047 * * *$ \\
\hline & $(0.011)$ & $(0.012)$ & $(0.012)$ & $(0.012)$ & $(0.011)$ \\
\hline \multirow[t]{2}{*}{ Wave 3} & $-0.167 * * *$ & $-0.064 * * *$ & $-0.180^{* * *}$ & $-0.305^{* * *}$ & $-0.523 * * *$ \\
\hline & $(0.012)$ & $(0.013)$ & $(0.013)$ & $(0.013)$ & $(0.014)$ \\
\hline \multirow[t]{2}{*}{ Wave 4} & $-0.209 * * *$ & $-0.048^{* * *}$ & $-0.137 * * *$ & $-0.257 * * *$ & $-0.457 * * *$ \\
\hline & $(0.012)$ & $(0.013)$ & $(0.014)$ & $(0.014)$ & $(0.014)$ \\
\hline \multirow[t]{2}{*}{ Wave 5} & $-0.210 * * *$ & $-0.076^{* * *}$ & $-0.187 * * *$ & $-0.214^{* * *}$ & $-0.472 * * *$ \\
\hline & $(0.012)$ & $(0.013)$ & $(0.014)$ & $(0.014)$ & $(0.014)$ \\
\hline \multirow[t]{2}{*}{ Wave 6} & $-0.080 * * *$ & -0.001 & -0.018 & 0.009 & $-0.307 * * *$ \\
\hline & $(0.012)$ & $(0.013)$ & $(0.014)$ & $(0.014)$ & $(0.014)$ \\
\hline \multirow[t]{2}{*}{ Intercept } & $4.781 * * *$ & $5.429 * * *$ & $5.298 * * *$ & $3.315 * * *$ & $3.305^{* * *}$ \\
\hline & $(0.082)$ & $(0.087)$ & $(0.092)$ & $(0.100)$ & $(0.080)$ \\
\hline Observations & 128,680 & 128,680 & 128,680 & 128,680 & 128,680 \\
\hline$R^{2}$ & 0.080 & 0.044 & 0.081 & 0.098 & 0.171 \\
\hline \multicolumn{6}{|c|}{ Robust standard errors in parentheses (clustered at the individual) } \\
\hline \multicolumn{6}{|c|}{${ }^{\#}$ Age and number of working hours have been divided by 10} \\
\hline \multicolumn{6}{|l|}{$* * * p$ value $<0.001$} \\
\hline \multicolumn{6}{|l|}{$* * p$ value $<0.01$} \\
\hline$* p$ value $<0.05$ & & & & & \\
\hline
\end{tabular}

\section{Discussion and conclusion}

This study is the first to conduct an empirical analysis of subjective well-being levels of freelancers. We compared their subjective well-being with other self- employed workers and provided an explanation behind these observed differences. We did so by using longitudinal data from the UK over the period 2009-2015. The motivation for our study was that the group of freelancers has increased substantially in the UK (and other 
European countries) over the past years. We pointed at the uncertainty and riskiness of this type of work and were interested in the drivers of freelancers to engage in such behaviour by investigating the perceived benefits of freelancers about which no prior work has appeared.

Our analysis of the subjective well-being levels of freelancers reveals that in terms of overall subjective well-being the freelancers, despite the uncertainty and riskiness surrounding their work, are on par with other self-employment groups (other own-account workers and employers) and wage workers. That is, we do not observe any significant life satisfaction differences between freelancers and other groups of workers while controlling for a wide range of important individuallevel variables affecting life satisfaction. This result is validated in our fixed-effects specification that explores the within-individual variation over time.

For several domains of life satisfaction, however, we observe differences between freelancers, other ownaccount workers and employers. This is clearly an important message for future research on the same topic: rather than focusing on the commonly investigated concept of life satisfaction integrating several subdomains into one analysis reveals much of how different groups of self-employed workers (and wage workers) score regarding their satisfaction with life.

The largest "gain" for freelancers can be observed for satisfaction with their leisure time (while controlling for the number of working hours in the analysis). We find particularly high levels of satisfaction with leisure time among the freelancers. That is, freelancers are significantly more satisfied with their leisure time than the other own-account workers, employers and wage workers. This is a remarkable result given earlier research on satisfaction differences between self-employed workers and wage workers. That is, in an earlier attempt to unravel well-being differences between the selfemployed and wage workers, we observed large and persistent drops in leisure satisfaction among those who switch from wage employment to selfemployment (Van der Zwan et al. 2018). The present research reveals that these drops are not observed for the freelancers (this is confirmed in our fixedeffects specification). This is in line with the earlier finding of significantly lower perceived levels of stress with work among own-account workers compared with employers and wage workers (Hessels et al. 2017). Possibly, this result is explained by the high flexibility that freelancers enjoy in terms of work place (home-based) (Storey et al. 2005) and work rhythm. According to our data, freelancers indicate more often than the other employment groups to work from home and less often to have a fixed rhythm of work (see Section 4.3).

Future research could include a wider range of job characteristics to explain subjective well-being differences between freelancers and other groups of workers. Another avenue for future research in explaining the result of leisure satisfaction is the incorporation of one's satisfaction with his/her balance between working and non-working activities (work-life balance). Given our preliminary findings in an additional dataset (Section 4.3), we note that freelancing may be an attractive labour market option for wage workers who wish to combine their working life with their non-working life in a satisfactory way. The possibility of switching occupations could be an important message to be communicated by governments that are focused on the contemporary issue of improving work-life balance levels among its citizens. At the same time, there seems to be room for improvement - also from the viewpoint of policy makers - in terms of the relatively low leisure satisfaction levels among employers.

Freelancers also score significantly better in terms of work satisfaction compared with wage workers, which may be explained by the higher level of experienced job autonomy among freelancers compared with wage workers, or when wage workers switch to freelancing over time. Despite the gains in leisure satisfaction among freelancers compared with other own-account and employers as described above, we do not find such a premium in terms of work satisfaction. Again, job autonomy may be an explanation here, because we find lower job autonomy among freelancers compared with other own-account workers and employers, and because job autonomy is important for freelancers in terms of satisfaction with their career (Van den Born and Van Witteloostuijn 2013).

The finding for significantly lower income satisfaction levels among the freelancers compared with employers as found in our cross-sectional analysis validates the uncertainty and riskiness of freelancing jobs. Differences in terms of income satisfaction disappear in our fixed-effects specification. All in all, these findings do not match well with the relatively high level of education that freelancers have (see Table 1). Future research should focus on explaining earnings of freelancers and 
Table 3 Fixed-effects regressions with satisfaction with life, work, leisure time, income and health as dependent variables

\begin{tabular}{|c|c|c|c|c|c|}
\hline & $\begin{array}{l}(1) \\
\text { Life }\end{array}$ & $\begin{array}{l}(2) \\
\text { Work }\end{array}$ & $\begin{array}{l}(3) \\
\text { Leisure }\end{array}$ & $\begin{array}{l}\text { (4) } \\
\text { Income }\end{array}$ & $\begin{array}{l}\text { (5) } \\
\text { Health }\end{array}$ \\
\hline \multicolumn{6}{|c|}{ Employment (reference: “freelancers") } \\
\hline Other own-account workers & $\begin{array}{l}-0.078 \\
(0.049)\end{array}$ & $\begin{array}{l}0.050 \\
(0.045)\end{array}$ & $\begin{array}{l}-0.123^{*} \\
(0.054)\end{array}$ & $\begin{array}{l}-0.089 \\
(0.056)\end{array}$ & $\begin{array}{l}-0.034 \\
(0.059)\end{array}$ \\
\hline Employers & $\begin{array}{l}-0.071 \\
(0.086)\end{array}$ & $\begin{array}{l}0.048 \\
(0.072)\end{array}$ & $\begin{array}{l}-0.286^{* *} \\
(0.090)\end{array}$ & $\begin{array}{l}-0.012 \\
(0.096)\end{array}$ & $\begin{array}{l}-0.099 \\
(0.099)\end{array}$ \\
\hline Wage workers & $\begin{array}{l}-0.085 \\
(0.053)\end{array}$ & $\begin{array}{l}-0.361 * * * \\
(0.055)\end{array}$ & $\begin{array}{l}-0.266^{* * * *} \\
(0.061)\end{array}$ & $\begin{array}{l}-0.118 \\
(0.062)\end{array}$ & $\begin{array}{l}-0.165^{* *} \\
(0.063)\end{array}$ \\
\hline Age $^{\#}$ & $\begin{array}{l}0.248 \\
(0.188)\end{array}$ & $\begin{array}{l}-0.429 * \\
(0.185)\end{array}$ & $\begin{array}{l}-0.413 \\
(0.245)\end{array}$ & $\begin{array}{l}-0.441 * \\
(0.202)\end{array}$ & $\begin{array}{l}-0.163 \\
(0.206)\end{array}$ \\
\hline Age squared ${ }^{\#}$ & $\begin{array}{l}0.026^{*} \\
(0.010)\end{array}$ & $\begin{array}{l}0.038 * * * \\
(0.011)\end{array}$ & $\begin{array}{l}0.052 * * * \\
(0.012)\end{array}$ & $\begin{array}{l}0.056 * * * \\
(0.012)\end{array}$ & $\begin{array}{l}0.026^{*} \\
(0.012)\end{array}$ \\
\hline \multicolumn{6}{|l|}{ Marital status (reference: "single") } \\
\hline Married & $\begin{array}{l}0.003 \\
(0.028)\end{array}$ & $\begin{array}{l}0.016 \\
(0.029)\end{array}$ & $\begin{array}{l}-0.015 \\
(0.031)\end{array}$ & $\begin{array}{l}0.029 \\
(0.031)\end{array}$ & $\begin{array}{l}-0.027 \\
(0.032)\end{array}$ \\
\hline Separated/divorced/widowed & $\begin{array}{l}-0.212 * * * \\
(0.041)\end{array}$ & $\begin{array}{l}-0.015 \\
(0.038)\end{array}$ & $\begin{array}{l}0.009 \\
(0.042)\end{array}$ & $\begin{array}{l}-0.148^{* * *} \\
(0.044)\end{array}$ & $\begin{array}{l}-0.029 \\
(0.046)\end{array}$ \\
\hline Children at home & $\begin{array}{l}0.023 \\
(0.020)\end{array}$ & $\begin{array}{l}-0.012 \\
(0.021)\end{array}$ & $\begin{array}{l}-0.175^{* * * *} \\
(0.023)\end{array}$ & $\begin{array}{l}-0.057 * \\
(0.022)\end{array}$ & $\begin{array}{l}-0.021 \\
(0.024)\end{array}$ \\
\hline Weekly working hours ${ }^{\#}$ & $\begin{array}{l}-0.007 \\
(0.007)\end{array}$ & $\begin{array}{l}0.004 \\
(0.008)\end{array}$ & $\begin{array}{l}-0.133^{* * * *} \\
(0.008)\end{array}$ & $\begin{array}{l}0.048 * * * \\
(0.008)\end{array}$ & $\begin{array}{l}0.004 \\
(0.008)\end{array}$ \\
\hline Log monthly net income & $\begin{array}{l}0.020 * \\
(0.010)\end{array}$ & $\begin{array}{l}0.037 * * * \\
(0.010)\end{array}$ & $\begin{array}{l}-0.046^{* * * *} \\
(0.011)\end{array}$ & $\begin{array}{l}0.116^{* * *} \\
(0.011)\end{array}$ & $\begin{array}{l}0.019 \\
(0.011)\end{array}$ \\
\hline \multicolumn{6}{|l|}{ Health (reference: "poor") } \\
\hline Fair & $\begin{array}{l}0.306^{* * * *} \\
(0.042)\end{array}$ & $\begin{array}{l}0.202 * * * \\
(0.045)\end{array}$ & $\begin{array}{l}0.060 \\
(0.041)\end{array}$ & $\begin{array}{l}0.141 * * * \\
(0.041)\end{array}$ & $\begin{array}{l}0.780 * * * \\
(0.043)\end{array}$ \\
\hline Good & $\begin{array}{l}0.514 * * * \\
(0.042)\end{array}$ & $\begin{array}{l}0.328 * * * \\
(0.046)\end{array}$ & $\begin{array}{l}0.205 * * * \\
(0.042)\end{array}$ & $\begin{array}{l}0.284 * * * \\
(0.042)\end{array}$ & $\begin{array}{l}1.364 * * * \\
(0.045)\end{array}$ \\
\hline Very good & $\begin{array}{l}0.650 * * * \\
(0.043)\end{array}$ & $\begin{array}{l}0.422 * * * \\
(0.046)\end{array}$ & $\begin{array}{l}0.342 * * * \\
(0.043)\end{array}$ & $\begin{array}{l}0.409 * * * \\
(0.042)\end{array}$ & $\begin{array}{l}1.736 * * * \\
(0.046)\end{array}$ \\
\hline Excellent & $\begin{array}{l}0.740 * * * \\
(0.044)\end{array}$ & $\begin{array}{l}0.490 * * * \\
(0.047)\end{array}$ & $\begin{array}{l}0.448 * * * \\
(0.044)\end{array}$ & $\begin{array}{l}0.476^{* * * *} \\
(0.044)\end{array}$ & $\begin{array}{l}1.939 * * * \\
(0.048)\end{array}$ \\
\hline \multicolumn{6}{|c|}{ Sector (reference: "manufacturing") } \\
\hline Administrative/support & $\begin{array}{c}-0.097 \\
(0.057)\end{array}$ & $\begin{array}{l}-0.132 \\
(0.078)\end{array}$ & $\begin{array}{l}0.003 \\
(0.068)\end{array}$ & $\begin{array}{l}-0.135^{*} \\
(0.065)\end{array}$ & $\begin{array}{l}-0.003 \\
(0.068)\end{array}$ \\
\hline Agriculture/mining & $\begin{array}{c}-0.105 \\
(0.142)\end{array}$ & $\begin{array}{l}0.172 \\
(0.191)\end{array}$ & $\begin{array}{l}-0.035 \\
(0.168)\end{array}$ & $\begin{array}{c}-0.158 \\
(0.153)\end{array}$ & $\begin{array}{l}0.083 \\
(0.162)\end{array}$ \\
\hline Arts/entertainment/recreation & $\begin{array}{c}-0.073 \\
(0.071)\end{array}$ & $\begin{array}{c}-0.004 \\
(0.096)\end{array}$ & $\begin{array}{l}-0.105 \\
(0.090)\end{array}$ & $\begin{array}{l}-0.236^{* *} \\
(0.089)\end{array}$ & $\begin{array}{l}-0.007 \\
(0.090)\end{array}$ \\
\hline Construction & $\begin{array}{c}-0.017 \\
(0.070)\end{array}$ & $\begin{array}{c}-0.118 \\
(0.093)\end{array}$ & $\begin{array}{l}0.115 \\
(0.081)\end{array}$ & $\begin{array}{c}-0.116 \\
(0.080)\end{array}$ & $\begin{array}{c}-0.054 \\
(0.079)\end{array}$ \\
\hline Education & $\begin{array}{c}-0.011 \\
(0.057)\end{array}$ & $\begin{array}{l}0.276 * * * \\
(0.078)\end{array}$ & $\begin{array}{l}0.003 \\
(0.068)\end{array}$ & $\begin{array}{l}-0.039 \\
(0.066)\end{array}$ & $\begin{array}{l}-0.008 \\
(0.069)\end{array}$ \\
\hline Electricity/water & $\begin{array}{l}-0.039 \\
(0.092)\end{array}$ & $\begin{array}{l}-0.190 \\
(0.141)\end{array}$ & $\begin{array}{l}0.066 \\
(0.120)\end{array}$ & $\begin{array}{l}0.061 \\
(0.109)\end{array}$ & $\begin{array}{l}0.013 \\
(0.120)\end{array}$ \\
\hline
\end{tabular}


Table 3 (continued)

\begin{tabular}{|c|c|c|c|c|c|}
\hline & $\begin{array}{l}\text { (1) } \\
\text { Life }\end{array}$ & $\begin{array}{l}\text { (2) } \\
\text { Work }\end{array}$ & $\begin{array}{l}(3) \\
\text { Leisure }\end{array}$ & $\begin{array}{l}\text { (4) } \\
\text { Income }\end{array}$ & $\begin{array}{l}(5) \\
\text { Health }\end{array}$ \\
\hline \multirow[t]{2}{*}{ Finance/insurance } & $-0.139 *$ & -0.191 & -0.023 & $-0.176^{*}$ & -0.161 \\
\hline & $(0.067)$ & $(0.105)$ & $(0.089)$ & $(0.081)$ & $(0.090)$ \\
\hline \multirow[t]{2}{*}{ Food services } & -0.111 & $-0.312 * * *$ & $-0.162^{*}$ & -0.084 & 0.013 \\
\hline & $(0.059)$ & $(0.078)$ & $(0.071)$ & $(0.066)$ & $(0.071)$ \\
\hline \multirow[t]{2}{*}{ Health } & -0.011 & $0.188^{*}$ & 0.041 & -0.062 & -0.035 \\
\hline & $(0.054)$ & $(0.076)$ & $(0.063)$ & $(0.062)$ & $(0.064)$ \\
\hline \multirow[t]{2}{*}{ Information/communication } & -0.070 & -0.079 & -0.016 & 0.086 & -0.097 \\
\hline & $(0.068)$ & $(0.096)$ & $(0.082)$ & $(0.083)$ & $(0.084)$ \\
\hline \multirow[t]{2}{*}{ Other services } & -0.048 & $0.227^{*}$ & 0.002 & -0.130 & -0.094 \\
\hline & $(0.068)$ & $(0.091)$ & $(0.082)$ & $(0.082)$ & $(0.083)$ \\
\hline \multirow[t]{2}{*}{ Professional/scientific/technical } & 0.027 & 0.086 & -0.019 & -0.031 & -0.056 \\
\hline & $(0.056)$ & $(0.079)$ & $(0.067)$ & $(0.066)$ & $(0.068)$ \\
\hline \multirow[t]{2}{*}{ Public administration } & -0.015 & -0.061 & 0.078 & -0.041 & -0.036 \\
\hline & $(0.060)$ & $(0.086)$ & $(0.074)$ & $(0.073)$ & $(0.076)$ \\
\hline \multirow[t]{2}{*}{ Real estate } & $-0.300^{* *}$ & -0.141 & -0.192 & -0.176 & -0.198 \\
\hline & $(0.114)$ & $(0.166)$ & $(0.135)$ & $(0.140)$ & $(0.133)$ \\
\hline \multirow[t]{2}{*}{ Transport } & -0.080 & -0.154 & -0.122 & -0.150 & -0.043 \\
\hline & $(0.072)$ & $(0.095)$ & $(0.079)$ & $(0.082)$ & $(0.080)$ \\
\hline \multirow[t]{2}{*}{ Wholesale and retail trade } & $-0.180 * * *$ & $-0.330 * * *$ & $-0.171 * *$ & $-0.191 * * *$ & -0.109 \\
\hline & $(0.047)$ & $(0.068)$ & $(0.056)$ & $(0.057)$ & $(0.058)$ \\
\hline \multicolumn{6}{|l|}{ Wave (reference: "wave 1") } \\
\hline \multirow[t]{2}{*}{ Wave 2} & $-0.088 * * *$ & -0.004 & -0.006 & -0.006 & -0.025 \\
\hline & $(0.020)$ & $(0.021)$ & $(0.026)$ & $(0.022)$ & $(0.022)$ \\
\hline \multirow[t]{2}{*}{ Wave 3} & $-0.259 * * *$ & $-0.075^{*}$ & $-0.148^{* *}$ & $-0.311 * * *$ & $-0.517 * * *$ \\
\hline & $(0.036)$ & $(0.035)$ & $(0.047)$ & $(0.039)$ & $(0.040)$ \\
\hline \multirow[t]{2}{*}{ Wave 4} & $-0.355 * * *$ & -0.059 & -0.101 & $-0.274 * * *$ & $-0.458 * * *$ \\
\hline & $(0.052)$ & $(0.051)$ & $(0.069)$ & $(0.056)$ & $(0.058)$ \\
\hline \multirow[t]{2}{*}{ Wave 5} & $-0.412^{* * *}$ & -0.086 & -0.150 & $-0.241 * *$ & $-0.497 * * *$ \\
\hline & $(0.069)$ & $(0.066)$ & $(0.091)$ & $(0.074)$ & $(0.076)$ \\
\hline \multirow[t]{2}{*}{ Wave 6} & $-0.315 * * *$ & -0.008 & 0.047 & 0.002 & $-0.331 * * *$ \\
\hline & $(0.086)$ & $(0.082)$ & $(0.113)$ & $(0.092)$ & $(0.095)$ \\
\hline \multirow[t]{2}{*}{ Intercept } & $3.350 * * *$ & $6.093 * * *$ & $6.014 * * *$ & $4.312 * * *$ & $3.905 * * *$ \\
\hline & $(0.682)$ & $(0.660)$ & $(0.898)$ & $(0.730)$ & $(0.746)$ \\
\hline Observations & 128,680 & 128,680 & 128,680 & 128,680 & 128,680 \\
\hline Number of individuals & 41,109 & 41,109 & 41,109 & 41,109 & 41,109 \\
\hline$R^{2}$ (overall) & 0.006 & 0.015 & 0.068 & 0.065 & 0.157 \\
\hline$R^{2}$ (within) & 0.015 & 0.011 & 0.016 & 0.022 & 0.056 \\
\hline
\end{tabular}

Robust standard errors in parentheses (clustered at the individual)

\# Age and number of working hours have been divided by 10

$* * * p$ value $<0.001$

$* * p$ value $<0.01$

$* p$ value $<0.05$ 
specifically on disentangling factors that hinder or can help freelancers to translate their high levels of human capital into higher and more stable earnings.

Research has not focused extensively on health differences between freelancers, other own-account workers and employers. We find no significant differences in health satisfaction between freelancers, ownaccount workers and employers. The existing evidence on the relationship between entrepreneurship (versus wage work) and health generally resulted in a positive relationship: entrepreneurs seem to be healthier than wage workers (Rietveld et al. 2015, 2016). We find tentative evidence of higher levels of health satisfaction for freelancing than for wage work (in our fixed-effects specification). Future research should unravel whether the positive relationship between health and entrepreneurship as found in previous research indeed holds for the group of freelancers (compared with wage workers) by using an extensive set of health measures. Also, future research could compare such health measures among freelancers, other own-account workers and employers.

There is an important distinction to be made in future research which may have implications for the relationships being tested in the present paper. Individuals decide to become freelancers because of opportunity reasons - those who are lured into freelancing because of the attractiveness of the job-or necessity reasonsbecause of a lack of alternative employment options. Because opportunity-based freelancers are expected to make rational choices, they are probably the ones who protect themselves against social risks (Fachinger and Frankus 2015). Those who become freelancers out of necessity may be more concerned about their health and financial situation, which may negatively impact their overall well-being levels. In addition to the distinction between opportunity-based and necessity-based freelancers, a more refined operationalisation of freelancing (for example by side jobs that people may have or a mixture between self-assessments and more objective measures) would be worthwhile to consider validating our results in other longitudinal samples.

Together with a significant increase of freelancers around the globe there have been concerns about the financial situation among this group and about their job security where the jobs are less predictable than the jobs of wage workers. Despite these adverse circumstances, we find that freelancers have relatively high levels of overall subjective well-being in terms of life satisfaction (they do not underperform compared with the other employment groups), and the largest benefit of freelancers is found for satisfaction with leisure time. Freelancers are also more satisfied with their work than wage workers. We find evidence that freelancers do not score lower for work and income satisfaction than own-account workers and employers, but future research should validate this in panel data settings covering more years. More research into this topic could result in advice for governments on how to relieve some of the (financial) concerns that freelancers experience.

Open Access This article is distributed under the terms of the Creative Commons Attribution 4.0 International License (http:// creativecommons.org/licenses/by/4.0/), which permits unrestricted use, distribution, and reproduction in any medium, provided you give appropriate credit to the original author(s) and the source, provide a link to the Creative Commons license, and indicate if changes were made.

\section{References}

Ambrey, C. L., \& Fleming, C. M. (2014). Life satisfaction in Australia: evidence from ten years of the HILDA survey. Social Indicators Research, 115(2), 691-714. https://doi. org/10.1007/s11205-012-0228-0.

Andersson, P. (2008). Happiness and health: well-being among the self-employed. Journal of Socio-Economics, 37(1), 213-236. https://doi.org/10.1016/j.socec.2007.03.003.

Anxo, D., \& Ericson, T. (2015). Self-employment and parental leave. Small Business Economics, 45(4), 751-770. https://doi.org/10.1007/s11187-015-9669-6.

Benz, M., \& Frey, B. S. (2008). Being independent is a great thing: subjective evaluations of self-employment and hierarchy. Economica, 75(298), 362-383. https://doi.org/10.1111 j.1468-0335.2007.00594.x.

Beutell, N.J., Schneer, J.A., \& Alstete, J.W. (2014). Comparing self-employment aspirants with the presently self-employed. Journal of Small Business \& Entrepreneurship, 27(5), 407425.

Binder (2018). The way to wellbeing a multidimensional strategy for improving wellbeing of the self-employed. Centre for Research on Self-Employment. http://crse.co. $\mathrm{uk} /$ sites/default/files/The\%20Way\%20to\%20Wellbeing\%20 Full\%20Report_0.pdf. Accessed 10 May 2019.

Binder, M., \& Coad, A. (2013). Life satisfaction and self-employment: a matching approach. Small Business Economics, 40(4), 1009-1033. https://doi.org/10.1007/s11187-0119413-9.

Binder, M., \& Coad, A. (2016). How satisfied are the selfemployed? A life domain view. Journal of Happiness Studies, 17(4), 1409-1433. https://doi.org/10.1007/s10902015-9650-8. 
Blanchflower, D. G. (2004). Self-employment: more may not be better. Swedish Economic Policy Review, 11, 15-73.

Blanchflower, D. . G., \& Oswald, A. J. (1998). What makes an entrepreneur? Journal of Labor Economics, 16(1), 26-60. https://doi.org/10.1086/209881.

Burke, A. (2015). Introduction: a freelancing and self-employment research agenda. In: A. Burke (Ed.), The handbook of research on freelancing and self-employment, pp. iii-viii. Dublin, Ireland: Senate Hall.

Cheung, F., \& Lucas, R. E. (2014). Assessing the validity of single-item life satisfaction measures: results from three large samples. Quality of Life Research, 23(10), 2809-2818. https://doi.org/10.1007/s11136-014-0726-4.

Di Tella, R., MacCulloch, R. J., \& Oswald, A. J. (2003). The macroeconomics of happiness. Review of Economics and Statistics, 85(4), 809-827.

Diener, E. D., Emmons, R. A., Larsen, R. J., \& Griffin, S. (1985). The satisfaction with life scale. Journal of Personality Assessment, 49(1), 71-75.

Diener, E., Suh, E. M., Lucas, R. E., \& Smith, H. L. (1999). Subjective well-being: three decades of progress. Psychological Bulletin, 125(2), 276-302. https://doi. org/10.1037/0033-2909.125.2.276.

Dolan, P., Peasgood, T., \& White, M. (2008). Do we really know what makes us happy? A review of the economic literature on the factors associated with subjective well-being. Journal of Economic Psychology, 29(1), 94-122. https://doi. org/10.1016/j.joep.2007.09.001.

Erdogan, B., Bauer, T. N., Truxillo, D. M., \& Mansfield, L. R. (2012). Whistle while you work a review of the life satisfaction literature. Journal of Management, 38(4), 1038-1083. https://doi.org/10.1177/0149206311429379.

Fachinger, U., \& Frankus, A. (2015). Freelancers, selfemployment and the insurance against social risks. In: A. Burke (Ed.), The handbook of research on freelancing and self-employment, pp. 135-146. Dublin, Ireland: Senate Hall.

Ferrer-i-Carbonell, A., \& Frijters, P. (2004). How important is methodology for the estimates of the determinants of happiness? The Economic Journal, 114(497), 641-659. https://doi. org/10.1111/j.1468-0297.2004.00235.x.

Handy, C. B. (1989). The age of unreason. Cambridge: Harvard Business School Press.

Headey, B., Veenhoven, R., \& Wearing, A. (1991). Top-down versus bottom-up theories of subjective well-being. Social Indicators Research, 24, 81-100.

Hébert, R. F., \& Link, A. N. (1989). In search of the meaning of entrepreneurship. Small Business Economics, 1, 39-49. https://doi.org/10.1007/BF00389915.

Hessels, J., Millán, J. M., \& Román, C. (2015). The importance of being in control of business: work satisfaction of employers, own-account workers and employees. Tinbergen Institute Discussion Paper Series (TI 15-047/VII). https://papers. tinbergen.nl/15047.pdf. Accessed 7 August 2019.

Hessels, J., Rietveld, C. A., \& van der Zwan, P. (2017). Selfemployment and work-related stress: the mediating role of job control and job demand. Journal of Business Venturing, 32(2), 178-196. https://doi.org/10.1016/j. jbusvent.2016.10.007.

Hessels, J., Arampatzi, E., van der Zwan, P., \& Burger, M. (2018). Life satisfaction and self-employment in different types of occupations. Applied Economics Letters, 25(11), 734-740. https://doi.org/10.1080/13504851.2017.1361003.

Kara, A., \& Petrescu, M. (2018). Self-employment and its relationship to subjective well-being. International Review of Entrepreneurship, 16(1), 115-140.

Kitching, J. (2015). Tracking UK freelance workforce trends 1992-2015. In: A. Burke (Ed.), The handbook of research on freelancing and self-employment, pp. 15-28.

Kitching, J., \& Smallbone, D. (2012). Are freelancers a neglected form of small business? Journal of Small Business and Enterprise Development, 19(1), 74-91. https://doi. org/10.1108/14626001211196415.

Knies, G. (2016). Understanding society - The UK household longitudinal study: waves 1-6, user manual. Colchester: University of Essex.

Kunda, G., Barley, S. R., \& Evans, J. (2002). Why do contractors contract? The experience of highly skilled technical professionals in a contingent labor market. ILR Review, 55(2), 234 261. https://doi.org/10.1177/001979390205500203.

Larsson, J. P., \& Thulin, P. (2018). Independent by necessity? The life satisfaction of necessity and opportunity entrepreneurs in 70 countries. Small Business Economics, 1-14. doi https://doi.org/10.1007/s11187-018-0110-9.

Lazear, E. P. (2005). Entrepreneurship. Journal of Labour Economics, 23, 649-680.

Lynn, P. (2009). Sample design for understanding society. Colchester: Institute for Social and Economic Research, University of Essex.

Meager, N. (2015). Job quality and self-employment: is it (still) better to work for yourself. In: A. Burke (Ed.), The handbook of research on freelancing and self-employment, pp. 35-46. Dublin, Ireland: Senate Hall.

Oswald, A. J., Proto, E., \& Sgroi, D. (2015). Happiness and productivity. Journal of Labor Economics, 33(4), 789-822. https://doi.org/10.1086/681096.

Prottas, D. J., \& Thompson, C. A. (2006). Stress, satisfaction, and the work-family interface: a comparison of self-employed business owners, independents, and organizational employees. Journal of Occupational Health Psychology, 11(4), 366-378. https://doi.org/10.1037/1076-8998.11.4.366.

Rietveld, C. A., Kippersluis, H., \& Thurik, A. R. (2015). Selfemployment and health: barriers or benefits? Health Economics, 24(10), 1302-1313. https://doi.org/10.1002 /hec.3087.

Rietveld, C. A., Bailey, H., Hessels, J., \& van der Zwan, P. (2016). Health and entrepreneurship in four Caribbean Basin countries. Economics \& Human Biology, 21, 84-89. https://doi. org/10.1016/j.ehb.2015.12.004.

Salinas-Jiménez, M. M., Artès, J., \& Salinas-Jiménez, J. (2013). How do educational attainment and occupational and wageearner statuses affect life satisfaction? A gender perspective study. Journal of Happiness Studies, 14(2), 367-388. https://doi.org/10.1007/s10902-012-9334-6.

Schimmack, U., \& Oishi, S. (2005). The influence of chronically and temporarily accessible information on life satisfaction judgments. Journal of Personality and Social Psychology, 89(3), 395-406.

Sorgner, A., Fritsch, M., \& Kritikos, A. (2017). Do entrepreneurs really earn less? Small Business Economics, 49(2), 251-272. https://doi.org/10.1007/s11187-017-9874-6. 
Stephan, U., \& Roesler, U. (2010). Health of entrepreneurs versus employees in a national representative sample. Journal of Occupational and Organizational Psychology, 83(3), 717738. https://doi.org/10.1348/096317909X472067.

Storey, J., Salaman, G., \& Platman, K. (2005). Living with enterprise in an enterprise economy: Freelance and contract workers in the media. Human Relations, 58(8), 1033-1054. https://doi.org/10.1177/0018726705058502.

Van den Born, A., \& Van Witteloostuijn, A. (2013). Drivers of freelance career success. Journal of Organizational Behavior, 34(1), 24 46. https://doi.org/10.1002/job.1786.

Van der Zwan, P. \& Hessels, J. (2019). Solo self-employment and wellbeing: An overview of the literature and an empirical illustration. International Review of Entrepreneurship, 17(2).

Van der Zwan, P., Hessels, J., \& Rietveld, C. A. (2018). Selfemployment and satisfaction with life, work, and leisure.
Journal of Economic Psychology, 64, 73-88. https://doi. org/10.1016/j.joep.2017.12.001.

Van Stel, A., \& Van der Zwan, P. (2019). Analyzing the changing education distributions of solo self-employed and employer entrepreneurs in Europe. Small Business Economics. https://doi.org/10.1007/s11187-019-00243-9.

Warr P. (2018). Self-employment, personal values, and varieties of happiness-unhappiness. Journal of Occupational Health Psychology, 23(3), 388-401.

Publisher's note Springer Nature remains neutral with regard to jurisdictional claims in published maps and institutional affiliations. 